\title{
Identifikasi Fitur Dasar Laut Menggunakan Data Multibeam Echosounder (Studi Kasus: Perairan Utara Papua)
}

\author{
Identification of Seabed Features Using Echosounder Multibeam Data \\ (Case Study: Waters of Northern Papua)
}

\author{
Aldias Fanan Fauzy', Danar Guruh Pratomo*2, M. Rohmaneo Darminto ${ }^{3}$, Teguh Sulistian ${ }^{4}$ \\ ${ }^{1,2,3}$ Departemen Teknik Geomatika, FTSPK-ITS, Kampus ITS Sukolilo, Surabaya, 60111, Indonesia \\ ${ }^{4}$ Pusat Pemetaan Kelautan dan Lingkungan Pantai, Badan Informasi Geospasial, Cibinong, 16911, Indonesia \\ *Korespondensi penulis: guruh@geodesy.its.ac.id
}

Diterima : 14082020; Diperbaiki : 03092020; Disetujui : 06092020; Dipublikasi : 13112020

\begin{abstract}
Abstrak: Indonesia merupakan negara yang memiliki wilayah laut yang luas dengan topografi yang bervariasi. Proses identifikasi topografi membutuhkan teknologi dan pengetahuan terbaru. Untuk dapat mengidentifikasi fitur dasar laut diperlukan penelitian menggunakan teknologi akustik berupa multibeam echosounder sehingga dapat dibuat model kondisi bawah air. Pemetaan detail dasar laut ini memungkinkan untuk menghasilkan gambaran topografi bawah laut yang lebih jelas. Dalam penelitian ini dilakukan identifikasi mengenai keberadaan pegunungan bawah laut di lautan Utara Papua. Data yang digunakan dalam penelitian ini berasal dari survei batimetri menggunakan multibeam echosounder yang dihasilkan oleh Badan Informasi Geospasial (BIG) bekerja sama dengan Badan Pengkajian dan Penerapan Teknologi (BPPT) pada tahun 2019. Data yang diambil untuk mengoreksi data multibeam echosounder adalah SVP Data (Sound velocity profiler). Penelitian ini dilakukan di lautan bagian Utara Papua yang terbagi menjadi dua lokasi. Hasil identifikasi di lokasi pertama (Lokasi A) menunjukkan luas wilayah $57.666 \mathrm{~km}^{2}$ dengan ketinggian 1.978 meter. Objek tersebut terletak kedalaman minimum 1.164 meter dan kedalaman maksimum 3.142 meter. Sedangkan pada lokasi kedua (Lokasi B), ditemukan objek yang memiliki luas sebesar 81,134 km², pada kedalaman minimum 1.997 meter, kedalaman maksimum 3.056 meter, dan memiliki ketinggian 1.059 meter. Hasil identifikasi kedua objek menunjukkan bahwa ketinggian kedua objek tersebut lebih dari $1.000 \mathrm{~m}$, sehingga keduanya dapat dikategorikan sebagai gunung bawah laut atau seamount.
\end{abstract}

Copyright (C) 2020 Geoid. All rights reserved.

\begin{abstract}
Indonesia is a country that has vast sea territory with varied topograph. The topographic identification process requires the latest technology and knowledge. To be able to identify the existence of seabed features, research is needed using acoustic technology in the form of a multibeam echosounder so that models of underwater conditions can be made. This detailed mapping of the seabed is possible to produce a clearer underwater topographic picture. In this study, identification was carried out regarding the existence of undersea mountains in Papua's northern ocean. The data used in this study came from a bathymetry survey using the multibeam echosounder produced by the Badan Informasi Geospapsial (BIG) in collaboration with the Badan Pengkaji dan Penerapan Teknologi (BPPT) in 2019. The data taken to correct the multibeam echosounder data are SVP (Sound velocity profiler) data. This research was conducted in the northern ocean of Papua which is divided into two locations. Based on the identification, the first location (A) has an area of 57,666 $\mathrm{km}^{2}$ with 1,978 meters of height. This object is located at a minimum depth of 1,164 meters and a maximum depth of 3,142 meters. At the second location (B) were found an object with an area of 81,134 $\mathrm{km}^{2}$, at a minimum depth of 1,997 meters, a maximum depth of 3,056 meters. The height of this object is 1,059 meters. Based on the results these two objects have more than 1,000 meters of height, thus the object can be categorized as an undersea mountain or seamount.
\end{abstract}

Kata kunci : Perairan; Gunung Bawah Laut; Multibeam Echosounder 


\section{Pendahuluan}

Indonesia dikenal sebagai negara yang memiliki wilayah perairan yang sangat luas dimana duapertiga wilayahnya ditutupi oleh laut. Wilayah laut yang sangat luas dan topografi perairan yang sangat bervariasi maka dibutuhkan teknologi dan pengetahuan yang mampu melakukan identifikasi berbagai bentuk topografi tersebut. Salah satu bentuk topografi dasar perairan yang masih sangat jarang dilakukan penelitiannya adalah gunung bawah laut. Gunung bawah laut (seamount) merupakan puncak-puncak gunung yang muncul pada dasar samudera dengan ketinggian sampai beberapa ratus meter di atas topografi sekitarnya. Gunung bawah laut merupakan bagian yang berdiri sendiri dan kakinya mulai dari dasar laut. Puncak gunung dapat muncul ke permukaan air. Gunung ini menjulang tinggi mencapai permukaan laut atau tidak namun akarnya ada di dasar laut (Nababan, 2015).

Gunung-gunung tersebut banyak tersebar di perairan Indonesia. Keberadaan gunung bawah laut diharapkan pula diikuti dengan keberadaan mineral non hayati yang bersifat ekonomis berupa mineral logam seperti emas, perak, biji besi, nikel, kobal, krom dan juga mineral non logam seperti kaolin, fosfat, dan zeolit. Untuk dapat mengidentifikasi keberadaan gunung bawah laut beserta sebarannya diperlukan penelitian geologi terpadu, yang meliputi bentang alam (mengacu pada gunung modern) dan struktur geologi, sedangkan untuk mengetahui keberadaannya dapat menggunakan bantuan ilmu geofisika. Teknologi akustik ini digunakan untuk mendapatkan informasi dasar perairan khususnya di laut. Teknologi akustik multibeam echosounder menjadi salah satu komponen survei laut yang digunakan untuk melakukan pengukuran kedalaman laut secara cepat dan akurat, sehingga dapat dibuat model kondisi dasar perairan. Pemetaan detail dasar laut ini dimungkinkan dapat menghasilkan gambaran topografi bawah laut secara lebih jelas (Triarso dan Troa, 2016).

Pada penelitian kali ini dilakukan identifikasi terkait keberadaan gunung bawah laut yang ada di wilayah perairan utara Papua. Badan Informasi Geospasial (BIG) bekerjasama dengan Badan Pengkajian dan Penerapan Teknologi (BPPT) pada tahun 2019 telah melakukan survei batimetri menggunakan multibeam echosounder untuk memperoleh gambaran topografi dasar laut. Data yang diambil untuk mengidentifikasi kondisi topografi dasar laut di perairan utara Papua menggunakan data multibeam echosounder. Dalam penelitian kali ini juga akan dibahas mengenai proses pengolahan multibeam echosounder untuk mendapatkan informasi kedalaman dan kondisi topografi dasar laut di perairan utara Papua.

\section{Data dan Metode}

Lokasi penelitian terdapat di perairan wilayah utara Papua dengan koordinat $1^{\circ} 03^{\prime} 31,7371$ "LS hingga $1^{\circ} 20^{\prime} 40,0728^{\prime \prime L S}$ dan $140^{\circ} 01^{\prime} 3,2671$ "BT hingga $140^{\circ} 29 ' 53,2596 " B T$ dengan cakupan wilayah $21 \times 53 \mathrm{~km}$. Lokasi penelitian ini dipilih karena perlunya mengetahui topografi dasar laut yang ada di Perairan Utara Papua pada Survei Landas Kontinen yang dilakukan oleh BIG bekerjasama oleh BPPT pada tahun 2019.

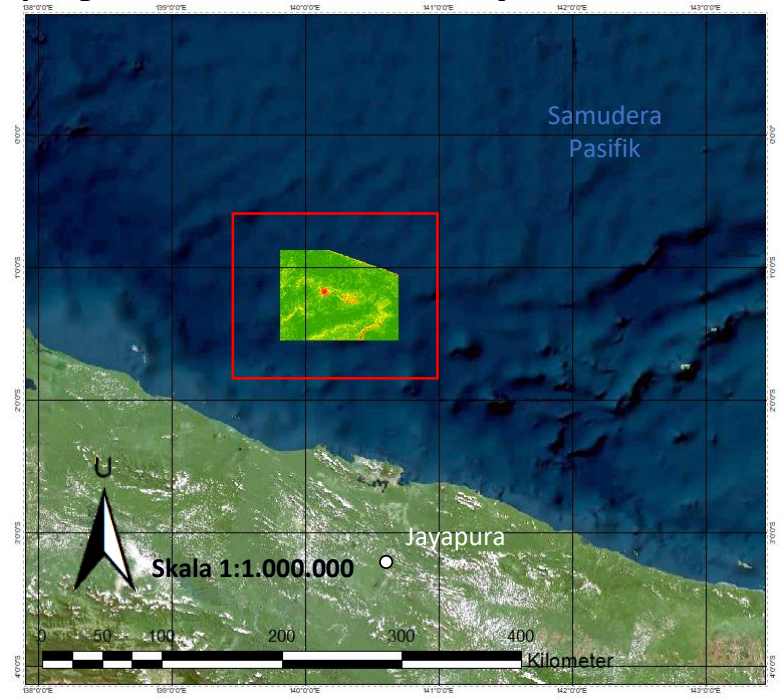

Gambar 1. Lokasi Penelitian 
Data dalam penelitian ini menggunakan data sekunder. Data sekunder pada penelitian ini adalah data raw multibeam echosounder dan data Sound Velocity Profiler pada area penelitian di tahun 2019. Peralatan yang digunakan dalam penelitian ini adalah beberapa perangkat lunak pengolahan data multibeam echosounder. Penelitian ini menggunakan Teledyne PDS untuk pengolahan data multibeam echosounder, ArcGIS 10.3, Surfer, dan Global Mapper yang digunakan untuk proses analisa dan identifikasi objek fitur dasar laut pada wilayah penelitian.

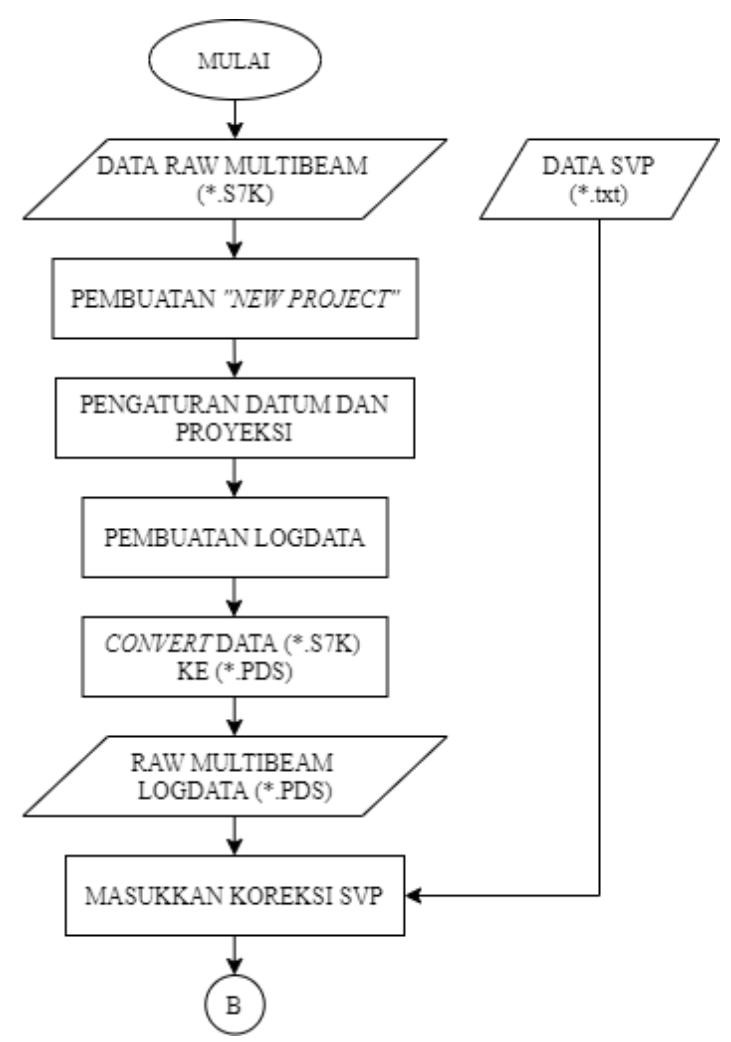

Gambar 2. Diagram Alir Tahapan Pengolahan Data

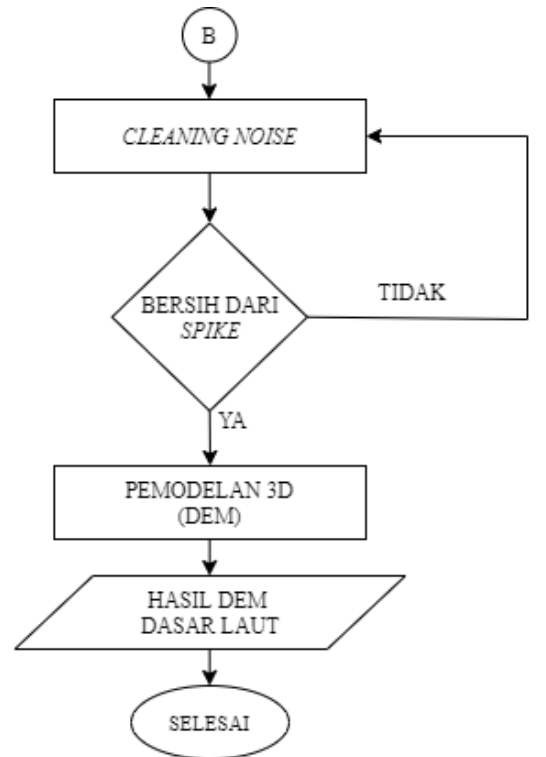

Gambar 3. Lanjutan Diagram Alir Tahapan Pengolahan Data 
Pada Gambar 2 dan Gambar 3 menunjukkan diagram alir tahap pengolahan data. Terdapat beberapa tahapan data yang akan diolah dalam penelitian ini, yaitu data multibeam echosounder dan sound velocity profile. Adapun tahapan pengolahan data yang dilakukan adalah sebagai berikut:

- Pembuatan "New Project". Lakukan pembuatan "New Project" pada pengolahan data sebelum melakukan pengolahan data pada software Teledyne PDS.

- Pengaturan Datum dan Proyeksi. Dikarenakan data kalibrasi Multibeam Echosounder sudah dimasukkan ketika akuisisi, sehingga untuk pengolahan data hanya tinggal melakukan pengaturan datum dan sistem proyeksi saja. Pada penelitian kali ini menggunakan datum "WGS 84" dan sistem proyeksi "Mercator"

- Pembuatan LogData. Melakukan copy Raw data Multibeam Echosounder (*.S7K) ke dalam folder "LogData" sebelum dilakukan pengolahan Raw data dan editing Raw data.

- Convert Data ke Dalam Format (*.PDS). Pengolahan data Multibeam Echosounder pada software Teledyne PDS harus menggunakan file dengan format (*.PDS). Oleh karena itu dilakukan convert data format (*.S7K) ke dalam format (*.PDS) dengan cara import file (*.S7K) yang sudah di copy pada folder "LogData"

- Memasukkan Koreksi Sound Velocity Profile (SVP). Dikarenakan Multibeam Echosounder yang digunakan adalah Teledyne Hydrosweep DS dengan pemasangan dilakukan secara permanen (Full Mounted) maka untuk parameter koreksi patch test sudah ada nilai tetap dan sudah dimasukkan koreksinya pada saat akusisi data berlangsung. Memasukkan koreksi Sound Velocity Profile (SVP) pada Raw data Multibeam Echosounder. Data koreksi Sound Velocity Profile (SVP) dengan format file (*.txt) memuat dua informasi data yaitu data kedalaman (depth) dan data kecepatan suara (sound velocity).

- Cleaning Noise. Proses Cleaning Noise bisa dilakukan ketika semua Raw data Multibeam Echosounder sudah terkoreksi. Proses Cleaning Noise dilakukan secara manual pada setiap file set dan satu lajur, dengan proses Cleaning pada setiap 50 ping. Setelah proses Cleaning Noise dilakukan maka dilakukan penggabungan data-data file set yang sudah bersih dari Spike atau Noise untuk selanjutnya dibuat pemodelan DEM

- Pemodelan DEM. Proses pemodelan DEM dilakukan setelah semua data digabungkan, DEM dari data hasil pengolahan Multibeam Echosounder dibuat dengan resolusi 100m. Setelah peroses pembuatan DEM langkah selanjutnya adalah proses analisa data hasil DEM tersebut untuk diidentifikasi gunung bawah laut (seamount) yang terdapat pada area tersebut.

\section{Hasil dan Pembahasan}

Pada penelitian ini diperoleh beberapa hasil yang dijelaskan sebagai berikut ini.

\section{Hasil dan Pembahasan Sound Velocity Profile}

Pengambilan data SVP di lokasi pada tanggal 21 Agustus 2019. Dengan menggunakan alat AML Minos X yang dicelupkan sampai ke dasar laut. Kedalaman maksimum adalah $3.900 \mathrm{~m}$ dan nilai rata - rata kecepatan rambat adalah $1.498,815 \mathrm{~m} / \mathrm{s}$. Nilai minimum adalah $1.482,837 \mathrm{~m} / \mathrm{s}$ pada kedalaman $940-941 \mathrm{~m}$ dan nilai maksimum adalah $1.543,016 \mathrm{~m} / \mathrm{s}$ pada kedalaman $27 \mathrm{~m}$.

Data Sound Velocity Profile dalam pengolahan Multibeam Echosounder sangat diperlukan untuk koreksi. Perbedaan data Multibeam Echosounder yang sudah terkoreksi Sound Velocity Profile dengan data Multibeam Echosounder yang belum terkoreksi Sound Velocity Profile akan jauh berbeda, terutama ketika dilakukan survei pada wilayah laut dalam (deep water). 


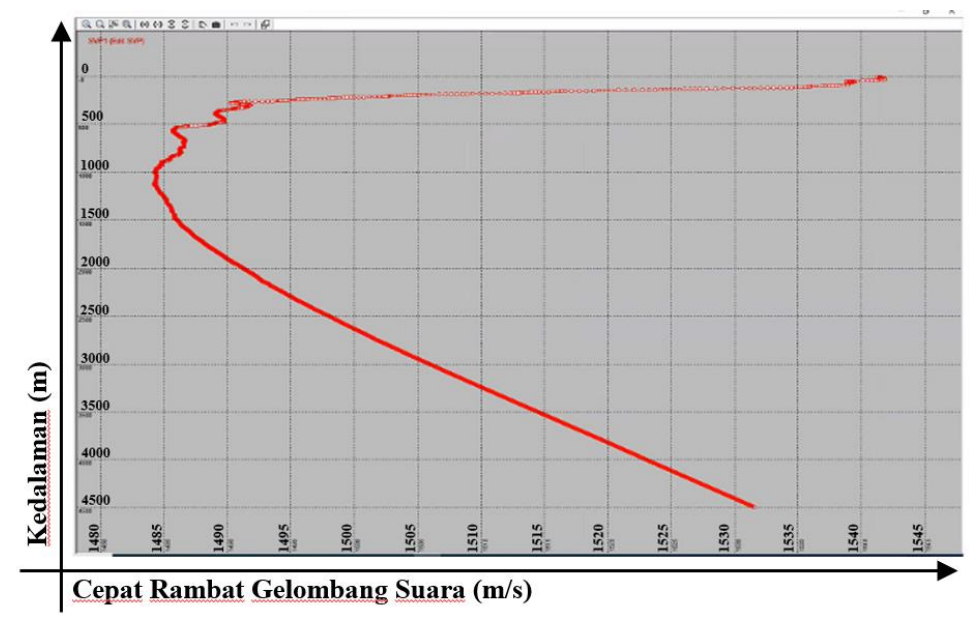

Gambar 4. Hasil Sound Velocity Profile pada Software Teledyne PDS

Berikut, Gambar 5 dan Gambar 6 merupakan perbandingan data Multibeam Echosounder yang sudah terkoreksi Sound Velocity Profile dengan data Multibeam Echosounder yang belum terkoreksi Sound Velocity Profile.



Gambar 5. Hasil Raw data Multibeam Echosounder yang belum terkoreksi Sound Velocity Profile Nilai Sound Velocity Profile

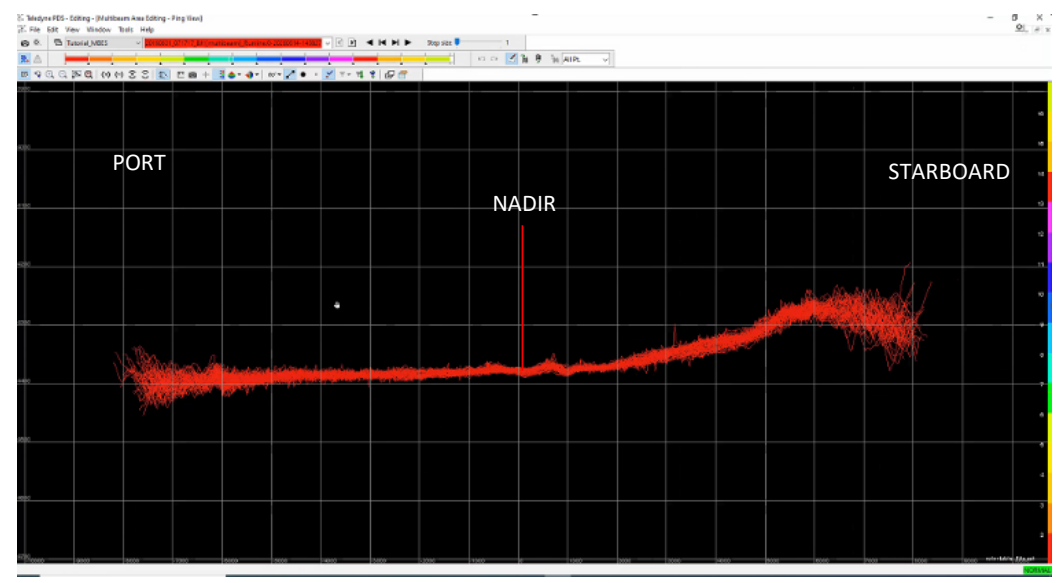

Gambar 6. Hasil Raw data Multibeam Echosounder yang sudah terkoreksi Sound Velocity Profile 


\section{Hasil dan Analisa Data Survei Multibeam Echosounder}

Batimetri didapatkan dari hasil akuisisi instrumen Multibeam Echosounder Teledyne Hidrosweep DS yang sudah terpasang pada kapal K/R Baruna Jaya 1. Pengolahan data Multibeam Echosounder menggunakan software Teledyne PDS dalam penelitian kali ini menghasilkan gambaran topografi dasar laut pada area penelitian. Gambar 7. menampilkan bentuk gambaran 2 dimensi (2D) dari hasil pengolahan data Multibeam Echosounder. Pada gambar tersebut memberikan informasi kedalaman area penelitian secara umum. Area penelitian memiliki kedalaman tertinggi sekitar 1.163 meter dan kedalam terendah 3.771 meter.

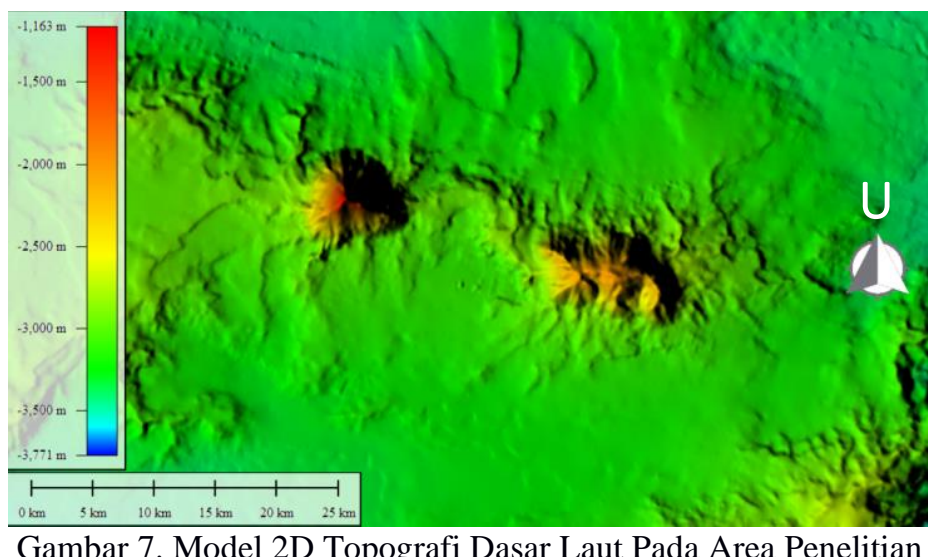

Hasil dari pengolahan data Multibeam Echosounder ini dapat membantu dalam memberikan informasi kedalaman serta bentukan topografi dasar laut. Gambar 8 menampilkan bentuk gambaran 3 dimensi (3D) dari hasil pengolahan data Multibeam Echosounder. Pada gambar tersebut memberikan informasi tentang kedalaman serta bentuk topografi dasar laut yang sangat bervariasi, sehingga dengan menggunakan pemodelan 3 dimensi (3D) akan mempermudah dalam identifikasi objek pada dasar perairan tersebut.

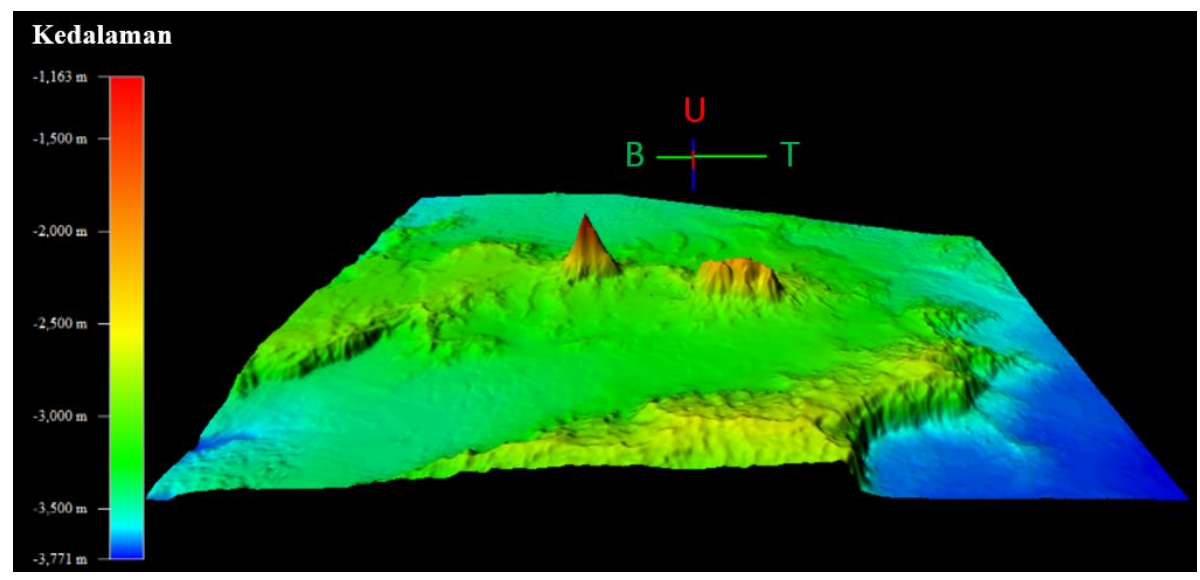

Gambar 8. Model 3D Topografi Dasar Laut Pada Area Penelitian

Terlihat pada Gambar 8 bahwa permukaan dasar laut (seabed surface) relatif bergelombang dengan perbedaan kedalaman yang sangat signifikan.

\section{Hasil dan Analisa Gunung Bawah Laut (Seamount)}

Dari pengolahan data Multibeam Echosounder terdapat dua objek pada area penelitian tersebut yang memiliki area yang luas dengan slope yang sangat tinggi yang mengidikasikan bahwa kedua objek tersebut merupakan gunung bawah laut (seamount). 


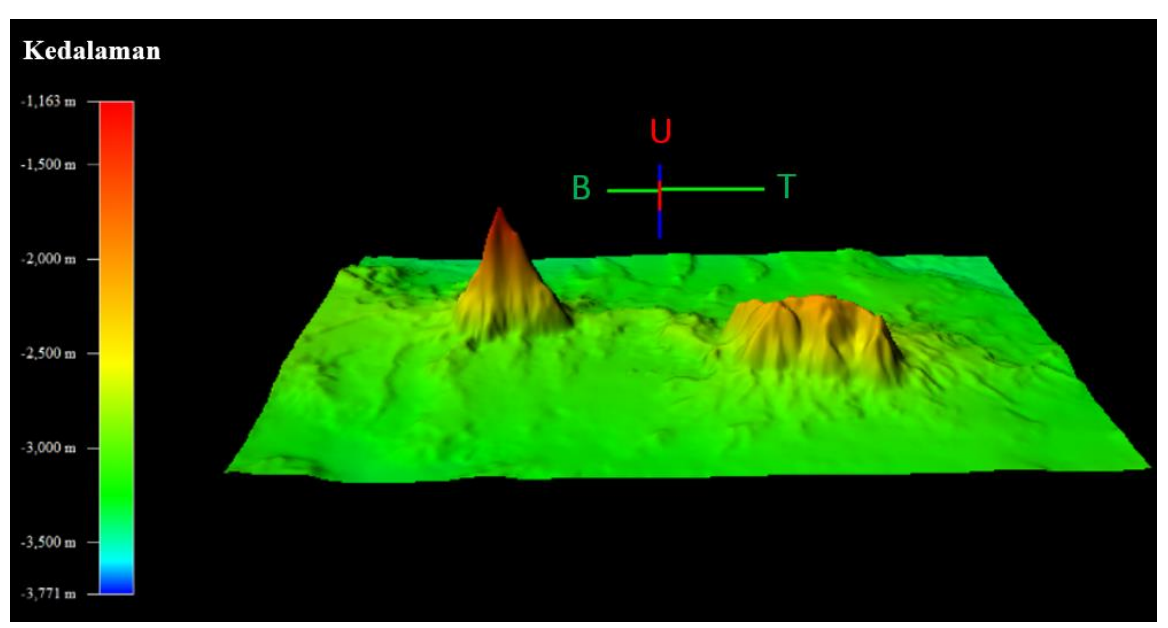

Gambar 9. Model 3D Gunung Bawah Laut (Seamount)

Terlihat pada Gambar 9. menampilkan bentuk gambaran 3 dimensi (3D) dari topografi gunung bawah laut (seamount) tersebut. Beberapa parameter yang digunakan dalam identifikasi topografi gunung bawah laut (seamount) adalah sebagai berikut:

\section{- Lokasi A}

Dari hasil identifikasi kondisi topografi yang dilakukan didapatkan luas gunung bawah laut (seamount) pada lokasi A sebesar $57,666 \mathrm{~km}^{2}$, penentuan luas didasari oleh penentuan kaki gunung sebagai batasan terluar gunung bawah laut. Kategori kaki gunung tersebut memiliki nilai kemiringan lereng sebesar $>16 \%$ (Nurwadjedi 2000). Gunung bawah laut ini memiliki kedalaman minimum sebesar 1.164 meter dan kedalaman maksimum sebesar 3.142 meter. Gunung bawah laut (seamount) pada lokasi A memiliki ketinggian 1.978 meter, sehingga dapat dikategorikan sebagai gunung atau pegunungan dikarenakan memiliki ketinggian yang lebih dari 1000 meter (Bermana, 2006).

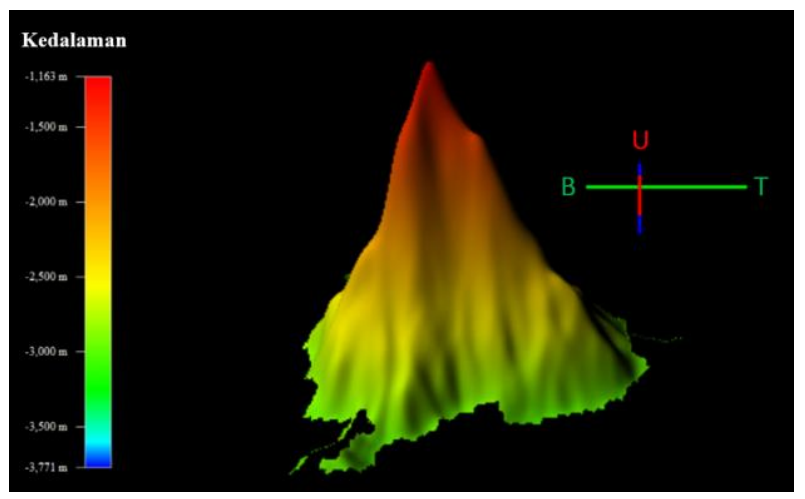

Gambar 10. Gunung Bawah Laut (Seamount) Lokasi A



Gambar 11. Penampang Melintang Gunung Bawah Laut (Seamount) Lokasi A 
Pada gambar Gambar 11. menampilkan penampang topografi pada gunung bawah laut (seamount) lokasi A dengan bentukan penampang yang menyerupai kerucut.

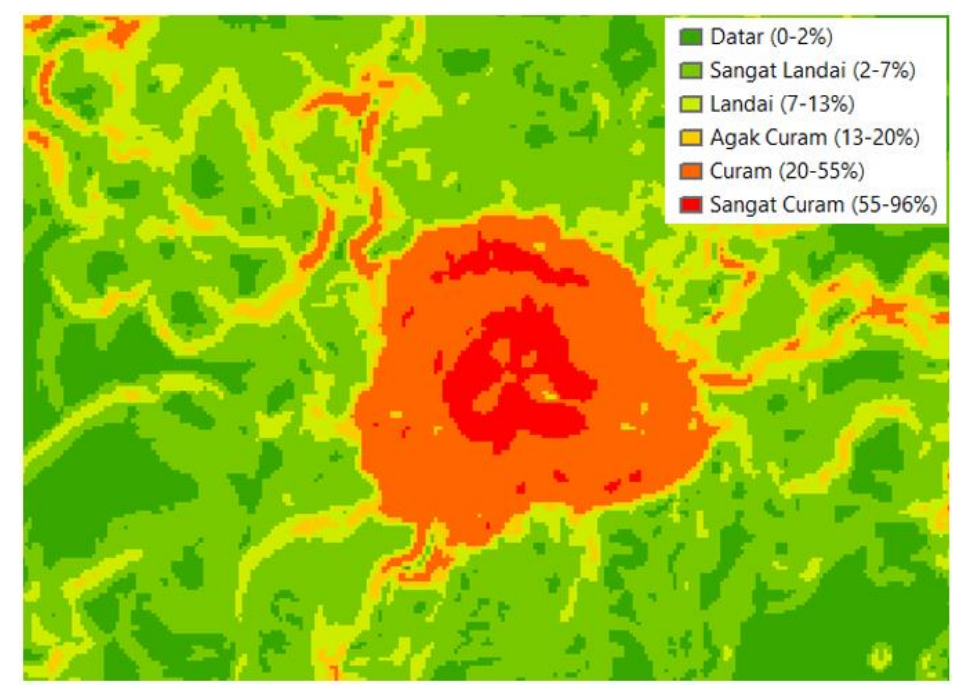

Gambar 12. Kemiringan Lereng Gunung Bawah Laut (Seamount) Lokasi A

Pada Gambar 12. terdapat kondisi kemiringan lereng (slope) pada lokasi A yang di dominasi oleh lereng yang curam dengan persentase kemiringan berkisar antara 20-55\% (Verstappen 1968; Van Zuidam, 1975).

Tabel 1. Klasifikasi Slope dan Luas Lokasi A

\begin{tabular}{llll}
\hline Slope $(\%)$ & Keterangan & Luas $\left(\mathbf{m}^{2}\right)$ & Luas $\left(\mathbf{k m}^{2}\right)$ \\
\hline $0-2$ & Datar & $25.615,532$ & 0,026 \\
\hline $2-7$ & Sangat Landai & $108.826,715$ & 0,109 \\
\hline $7-13$ & Landai & $2.528 .251,556$ & 2,528 \\
\hline $13-20$ & Agak Curam & $3.069 .938,168$ & 3,070 \\
\hline $20-55$ & Curam & $41.297 .372,880$ & 41,297 \\
\hline$>55$ & Sangat Curam & $10.524 .095,201$ & 10,524 \\
\hline
\end{tabular}

\section{- Lokasi B}

Dari hasil identifikasi kondisi topografi yang dilakukan didapatkan luas gunung bawah laut (seamount) pada lokasi B sebesar $81,134 \mathrm{~km}^{2}$, penentuan luas didasari oleh penentuan kaki gunung sebagai batasan terluar gunung bawah laut. Kategori kaki gunung tersebut memiliki nilai kemiringan lereng sebesar $>16 \%$ (Nurwadjedi 2000). Gunung bawah laut ini memiliki kedalaman minimum sebesar 1.997 meter dan kedalaman maksimum sebesar 3.056 meter. Gunung bawah laut (seamount) pada lokasi B memiliki ketinggian 1.059 meter, sehingga dapat dikategorikan sebagai gunung atau pegunungan dikarenakan memiliki ketinggian yang lebih dari 1000 meter (Bermana, 2006).



Gambar 13. Gunung Bawah Laut (Seamount) Lokasi B 


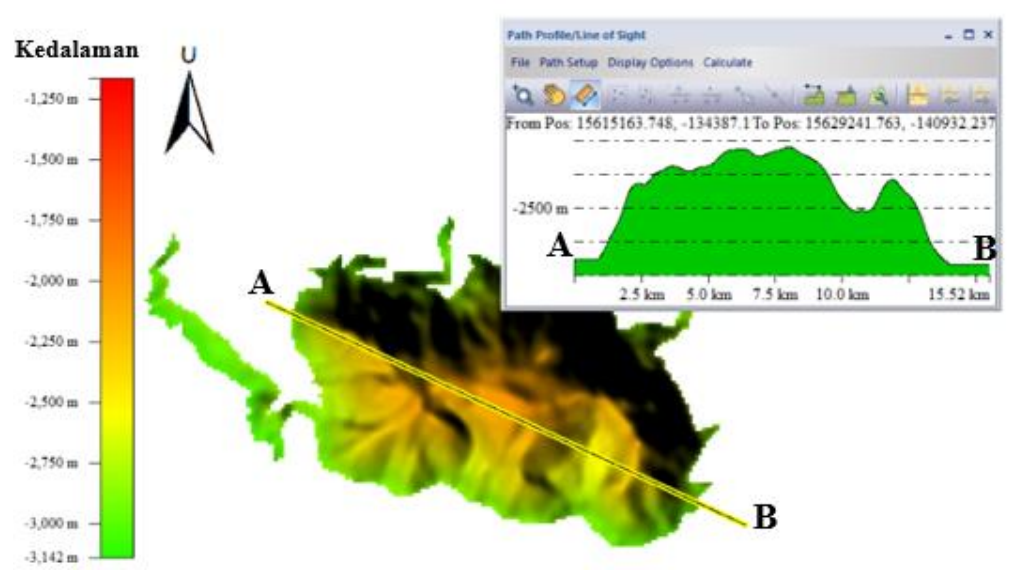

Gambar 14. Penampang Melintang Gunung Bawah Laut (Seamount) Lokasi B

Pada Gambar 14. menampilkan penampang topografi pada gunung bawah laut (seamount) lokasi B dengan bentukan penampang yang menyerupai mangkuk terbalik.

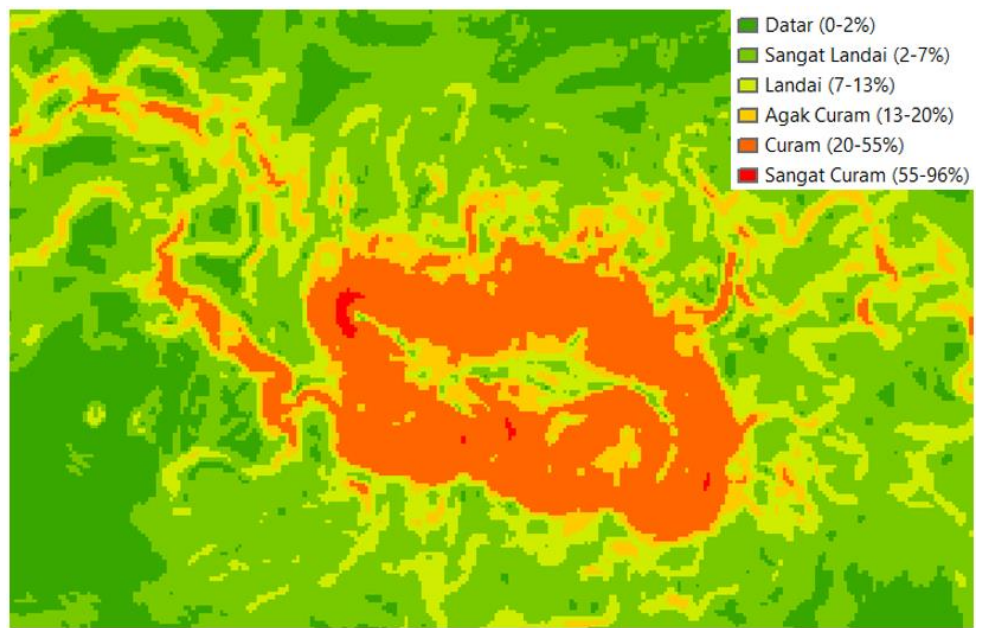

Gambar 15. Kemiringan Lereng Gunung Bawah Laut (Seamount) Lokasi B

Pada Gambar 15. terdapat kondisi kemiringan lereng (slope) pada lokasi B yang di dominasi oleh lereng yang curam dengan persentase kemiringan berkisar antara 20-55\% (Verstappen 1968; Van Zuidam 1975).

Tabel 2. Klasifikasi Slope dan Luas Lokasi B

\begin{tabular}{llll}
\hline Slope $(\boldsymbol{\%})$ & Keterangan & Luas $\left(\mathbf{m}^{\mathbf{2}}\right)$ & Luas $(\mathbf{k m})$ \\
\hline $0-2$ & Datar & $52.904,804$ & 0,053 \\
\hline $2-7$ & Sangat Landai & $1.191 .065,904$ & 1,191 \\
\hline $7-13$ & Landai & $8.125 .292,179$ & 8,125 \\
\hline $13-20$ & Agak Curam & $13.133 .449,061$ & 13,133 \\
\hline $20-55$ & Curam & $57.870 .813,402$ & 57,871 \\
\hline$>55$ & Sangat Curam & $690.134,952$ & 0,690 \\
\hline
\end{tabular}

\section{Kesimpulan}

Dari hasil identifikasi kedua gunung bawah laut (seamount) pada area penelitian di perairan utara Papua didapatkan hasil topografi bawah laut pada lokasi A memiliki luas sebesar 57,666 km² dengan kedalaman minimum sebesar 1.164 meter dan kedalaman maksimum sebesar 3.142 meter. Gunung bawah laut (seamount) pada lokasi A memiliki ketinggian 1.978 meter, sehingga dapat dikategorikan sebagai gunung atau 
pegunungan. Terdapat kondisi kemiringan lereng (slope) pada lokasi A yang di dominasi oleh lereng yang curam dengan persentase kemiringan berkisar antara 20-55\%. Sedangkan pada lokasi B memiliki luas sebesar $81,134 \mathrm{~km}^{2}$ dengan kedalaman minimum sebesar 1.997 meter dan kedalaman maksimum sebesar 3.056 meter. Gunung bawah laut (seamount) pada lokasi B memiliki ketinggian 1.059 meter, sehingga dapat dikategorikan sebagai gunung atau pegunungan. Terdapat kondisi kemiringan lereng (slope) pada lokasi B yang di dominasi oleh lereng yang curam dengan persentase kemiringan berkisar antara $20-55 \%$.

\section{Ucapan Terimakasih}

Penulis mengucapkan terima kasih kepada Badan Informasi Geospasial (BIG) yang telah menyediakan data multibeam echosounder dan Sound Velocity Profile (SVP) dari hasil survei LKI pada tahun 2019 untuk keperluan penelitian kali ini.

\section{Daftar Pustaka}

Bermana, I. (2006). Klasifikasi Geomorfologi Untuk Pemetaan Geologi Yang Telah Dibakukan. Bulletin of Scientific Contribution, 161-173.

Nababan, tF. V. (2015). Oseanografi Geologi Morfologi Dasar Laut. Semarang: Universitas Diponegoro.

Nurwadjedi. (2000). Klasifikasi Bentuklahan Semi Detil (Skala 1:50.000 / 1:25.000) Hasil Pengembangan Peta REPPPROT Skala 1:250.000. Globe, 72-83.

Triarso, E., \& Troa , R. A. (2016). Pemetaan Geologi Gunung Api Bawah Laut Kawio Barat Perairan Sangihe-Talaud Menggunakan Multibeam Echosounder Resolusi Tinggi. Jurnal Kelautan Nasional, 67-75.

Van Zuidam, R.A. (1982) Consideration on Systematic Medium Scale Geomorphological Mapping, Z. Geomorph.NF, Vol. 20.

Verstappen,H.Th. (1970) Introduction to the ITC - System of Geomorpholo-gy Survey. KNAG Geografisch Tijdschrift, Vol 4. 